\title{
Pengaruh Kepimpinan dalam Hubungan antara Keadilan Organisasi dan Politik Organisasi dalam Institusi Kewangan Islam di Malaysia
}

(The Influence of Leadership in the Relationship of Perceived Perception of Organizational Politics in Islamic Financial Organization Based at Malaysia)

\author{
Saiful Azizi Ismail \\ Zulkiflee Daud \\ (Pusat Pengajian Pengurusan Perniagaan, Universiti Utara Malaysia) \\ Ahmad Fauzi Ahmad Zaini \\ (Sekolah Perniagaan dan Perakaunan, Kolej Universiti Poly-Tech Mara)
}

\begin{abstract}
ABSTRAK
Kajian ini bertujuan menguji peranan perantara kepimpinan dalam hubungan antara keadilan organisasi dan persepsi politik organisasi. Berasaskan reka bentuk keratan rentas, sampel kajian ini melibatkan seramai 291 orang pekerja bukan pegawai daripada pelbagai institusi kewangan Islam di Malaysia. Kajian ini juga menunjukkan bahawa terdapat dimensi-dimensi baru yang wujud dalam keadilan organisasi dan politik organisasi di institusi kewangan Islam di Malaysia. Penemuan dimensi-dimensi baru dilihat dengan menggunakan analisis faktor. Kesan pengaruh antara keadilan organisasi, kepimpinan dan politik organisasi diuji dengan menggunakan analisis regresi berganda. Keputusan menunjukkan bahawa keadilan organisasi mempunyai kesan pengaruh yang signifikan dengan politik organisasi dan kepimpinan berperanan sebagai perantara dalam hubungan antara keadilan organsasi dan politik organisasi.
\end{abstract}

Kata kunci: Politik organisasi; keadilan organisasi; kepimpinan; institusi kewangan Islam

\section{ABSTRACT}

This study examined the mediating influence of leadership on the relationship between organizational justice and organizational politics. Based on cross-sectional design, the sample of this study consisted of 291 non-executive workers from various Islamic financial institution in Malaysia. This study also points to a new dimension of organizational justice and organizational politics in the Islamic financial institution in Malaysia. The discovery of new dimensions seen by using factor analysis. The effect of the influence of organizational justice, leadership and organizational politics were tested using multiple regression analysis. The results show that organizational justice has the effect of significant influence by organizational politics, and leadership role as mediator in the relationship between organizational justice and organizational politics.

Keywords: Organizational politics; organizational justice; leadership; Islamic financial institution 


\section{PENGENALAN}

Politik organisasi adalah satu perkara yang sukar difahami kerana mendorong ke arah hubungan kuasa di tempat kerja di mana ia melibatkan hubungan perorangan, ciri-ciri penglibatan secara langsung atau tidak langsung (aktif atau pasif) kepada pekerja yang menjalankan taktik pengaruh dan perebutan kuasa. Aktiviti politik organisasi ini adalah bertujuan untuk mendapatkan atau memaksimumkan kepentingan peribadi atau sebagai alternatif bagi mengelakkan hasil negatif dalam organisasi (Kacmar \& Ferris 1992). Politik organisasi merupakan perkara yang asas berlaku dalam perhubungan antara majikan dan pekerja (Gandz \& Murray 1980). Menurut Ullah, Jafri dan Dost (2011), politik organisasi mula mendapat perhatian yang tinggi di kalangan pekerja apabila konsep rasional organisasi dicabar kerana kemunculan konsep lain seperti pemilihan struktur organisasi yang tidak sesuai, ketidakserasian matlamat peribadi dan organisasi. Konsep rasional organisasi adalah berdasarkan idea bahawa individu menentukan matlamat mereka dengan melihat matlamat organisasi dan dijangka bekerja untuk mencapai matlamat peribadi mereka mengikut undangundang dan peraturan organisasi.

Kebiasaanya politik organisasi berlaku adalah disebabkan kewujudan pemanipulasian kuasa di dalam organisasi (Madison 1980). Kuasa adalah kebolehan untuk mempengaruhi pekerja bawahan supaya mengikut kehendak atau matlamat seseorang yang berjawatan tinggi dalam organisasi seperti pengurus syarikat (Yen, Chen \& Yen 2009). Politik Organisasi digunakan untuk melindungi atau meningkatkan kepentingan diri individu dan meneruskan kepentingan matlamat individu atau kumpulan (Vigoda 2000). Oleh yang demikian, Politik Organisasi berkemungkinan digunakan bagi tujuan penyalahgunaan kuasa dari individu atau kumpulan (Kacmar \& Ferris 1992).

Topik berhubung dengan politik organisasi telah menarik perhatian ramai pengkaji terutamanya dalam bidang pengurusan kerana ia sentiasa berlaku dan memberi kesan yang meluas ke atas proses kritikal dalam organisasi seperti penilaan prestasi, peruntukan sumber dan pengurusan dalam membuat keputusan (Sarminah 2011). Kesan ini mempengaruhi keberkesanan dan kecekapan organisasi (Kacmar \& Baron 1999). Kewujudan politik organisasi ini disebabkan oleh kesan yang mendalam terhadap pemanipulasian kuasa dalam organisasi (Madison 1980). Pemanipulasian kuasa yang dilakukan oleh pihak majikan seperti menjalankan penilaian prestasi yang tidak adil, membuat keputusan tidak berdasarkan laporan asal dan berlaku berat sebelah dalam pengurusan pentadbiran dalam organisasi.

Dalam persekitaran pekerjaan, Sektor Kewangan dan Insuran merupakan salah satu sektor yang menyumbang kepada ekonomi Malaysia (Unit Perancangan Ekonomi 2015). Penglibatan pekerja yang ramai dalam persekitaran tempat kerja mendorong kepada berlakunya politik organisasi (Feris \& King 1991). Berdasarkan laporan yang dikeluarkan oleh Mahkamah Perusahaan Malaysia dari tahun 2011 hingga 2017 terdapat 10 kes pertikaian yang dirujuk kepada mahkamah perusahaan iaitu di bawah seksyen 18 dan 26 Akta Perhubungan Perusahaan 1967. Kes-kes pertikaian yang wujud dalam mahkamah perusahaan ini membayangkan politik organisasi juga berlaku dalam institusi kewangan Islam di Malaysia.

Selain itu, kajian ini memberi sumbangan signifikan kepada literatur melalui beberapa perkara yang mana menerangkan tentang bagaimana keadilan organisasi menyumbang kepada politik organisasi. Kajian-kajian lepas menunjukkan hubungan langsung keadilan organisasi dan politik organisasi, dan dengan itu mengehadkan pengetahuan tentang mekanisme yang menghubungkan kedua-dua pemboleh ubah tersebut (Sikora \& Ferris 2014; Khan et al. 2015). Pertamanya, kajian ini menerangkan peranan kepimpinan sebagai perantara dalam menghubungkan kedua pemboleh ubah tersebut. Keduanya, kajian ini mengemukakan keadaan yang berpotensi mempengaruhi hubungan antara keadilan organisasi dan kepimpinan. Akhirnya, kajian ini juga menyumbang kepada literatur dalam konteks tempatan kerana 
sebahagian besar pengetahuan berhubung dengan peranan keadilan organisasi dan kepimpinan ke atas politik organisasi didominasi oleh literatur dari barat (Kimura 2013; Zulkiflee et al. 2013). Kajian-kajian dari barat biasanya dilihat dalam konteks yang berbeza kerana hubungan antara keadilan organisasi, kepimpinan dan politik organisasi tertakluk kepada faktor persekitaran dan budaya kerja (Ullah et al. 2011; Zhang et al. 2014).

Salah satu faktor yang berpotensi menyumbang kepada politik organisasi adalah keadilan organisasi (Kacmar et al. 2013; Colquitt et al. 2013; Kimura 2013). Kebiasaanya, kajian-kajian yang dibuat hanya melihat kepada hubungan secara langsung kesan keadilan organisasi dan politik organisasi, tetapi jarang meneliti mekanisme perantara yang menghubungkan atau menguatkan kedua pemboleh ubah tersebut. Ini menimbulkan persoalan berhubung proses bagaimana keadilan organisasi boleh membawa kepada politik organisasi. Ringkasnya, pengetahuan tentang pemboleh ubah perantara yang menghubungkan keadilan organisasi dan politik organisasi adalah terhad (Khan et al. 2015). Oleh yang demikian, kajian ini bertujuan untuk melihat peranan kepimpinan sebagai pemboleh ubah perantara dalam menghubungkan atau menguatkan keadilan organisasi dan politik organisasi.

\section{ULASAN LITERATUR}

\section{KEADILAN ORGANISASI DAN POLITIK ORGANISASI}

Politik adalah berkenaan dengan pengurusan dan proses membuat keputusan di dalam kumpulan sosial (Doldor 2007). Walaupun tingkah laku politik boleh menghasilkan kesan positif dan negatif tetapi dalam kajian yang dijalankan oleh Ferris dan King (1991) adalah lebih memberi tumpuan kepada kesan negatif. Politik yang berbentuk negatif adalah tingkah laku yang tidak dibenarkan oleh organisasi. Ini menunjukkan bahawa politik boleh klasifikasikan sebagai kepentingan diri seperti mengambil kredit dari kerja orang lain, membina penggabungan, serangan peribadi ke atas pekerja yang bersaing untuk sumber yang sama dan membuat keputusan berdasarkan faktor pilih kasih (Atinc et al. 2010). Tingkah laku politik ini merupakan satu proses yang membawa ke arah mewujudkan persekitaran kerja yang berbahaya dan memecah-belahkan keadaan, mengurangkan kecekapan dan keberkesanan organisasi, dan mempunyai kesan yang sangat berbahaya terhadap pekerja (Mintzberg 1993). Ini menunjukkan bahawa politik organisasi berlaku di kalangan pekerja-pekerja di dalam sesebuah organisasi.

Politik organisasi berlaku apabila seseorang mempengaruhi sesuatu proses yang telah digubal untuk menguruskan persaingan bagi kepentingan yang wujud dalam organisasi (Doldor 2011). Politik organisasi disebabkan oleh kewujudan pelbagai kepentingan dan matlamat individu yang tidak sesuai dan di luar matlamat organisasi dari teknik-teknik pengaruh yang digunakan seseorang untuk mempertahankan kepentingan mereka (Ullah et al. 2011). Pfeffer (1981) melihat politik organisasi sebagai satu aktiviti di dalam organisasi untuk memperoleh, membangun serta menggunakan kuasa dan sumber-sumber lain untuk seseorang pekerja mencapai kehendaknya dalam keadaan di mana sumber tersebut adalah terhad. Ini dipersetujui oleh Kurchner-Hawkins dan Miller (2006), politik organisasi adalah kuasa pengaruh yang berlaku di luar proses organisasi rasmi dan organisasi prosedur.

Keadilan organisasi dilihat sebagai satu persepsi individu yang ingin dilayan secara adil dan menuntut keadilan daripada organisasi mereka bekerja (Mohd Noor, Mohd Amir \& Maelah 2017). Keadilan organisasi dilihat sebagai keperluan kepada pekerja yang mana digunakan untuk menjaga kebajikan dan hak pekerja (Bakhsi, Kumar \& Rani 2009). Kebajikan dan hak pekerja termasuklah kesan terhadap sikap pekerja iaitu kepuasan kerja, kecenderungan pemberhentian kerja dan komitmen kerja (Colquitt et al. 2001). Kesan ini juga membawa pekerja kepada tingkah laku negatif di tempat kerja seperti ketidakhadiran kerja dan tingkah laku kekitaan organisasi. Keadilan organisasi boleh mempertingkatkan lagi sikap dan tingkah 
laku yang berkaitan dengan organisasi seperti kepuasan, komitmen yang berkesan, kepercayaan dan prestasi (Colquitt et al. 2001). Kajian-kajian lepas, keadilan organisasi lebih fokus kepada pembentukkan prestasi yang mempunyai hubungan kepada kerelaan pekerja untuk melaksanakan tugasan mereka (Fernandes \& Awamleh 2006). Hubungan ini lebih cenderung kepada tindak balas pekerja terhadap tingkah laku penentuan peranan kepada pekerjaan mereka (Suliman 2007).

Keadilan organisasi dilihat kepada tiga dimensi iaitu keadilan pengagihan, keadilan prosedur dan keadilan interaksi (Ambrose \& Schminke 2009). Ketiga-tiga keadilan ini merupakan dimensi yang memainkan peranan penting untuk menunjukkan bahawa keadilan organisasi berlaku di tempat kerja (Greenberg 1986). Keadilan pengagihan menunjukkan bahawa pekerja lebih fokus kepada keadilan dalam pemberian ganjaran yang mana ia diagih berdasarkan kepada asas ekuiti dan prestasi pekerja dalam organisasi (Iqbal 2013). Keadilan prosedur merupakan penting bagi menentukan sama ada sumber dan ganjaran yang diberikan kepada pekerja adalah adil atau tidak adil (Thibaut \& Walker 1978). Keputusan berkenaan dengan sumber dan ganjaran dibuat berdasarkan prosedur rasmi organisasi seperti polisi dan peraturan syarikat (Moorman 1991). Keadilan interaksi adalah berkaitan dengan keadilan komunikasi perorangan di mana mempunyai hubungan dengan prosedur organisasi (McDowall \& Fletcher 2004). Ini menunjukkan bagaimana cara maklumat itu disalurkan kepada pekerja sama ada secara sopan atau sivil (Bies \& Moag 1986).

Dalam meneliti perkaitan antara keadilan organisasi dan politik organisasi, pengkajipengkaji lepas didapati cenderung melihat hubungan secara langsung. Kajian ini berbeza dengan kajian lepas yang mana penyelidik meneliti satu pemboleh ubah yang berpotensi memainkan peranan dalam menerangkan bagaimana dan bila keadilan organisasi mempengaruhi politik organisasi. Kajian ini mengganggap kepimpinan bertindak sebagai perantara dalam hubungan antara keadilan organisasi dan politik organisasi. Ini bermaksud keadilan organisasi yang tinggi mungkin menyumbang kepada kepimpinan, dan berikutnya kepimpinan yang rendah mungkin meningkatkan politik organisasi.

\section{PERANAN KEPIMPINAN SEBAGAI PERANTARA}

Kepimpinan adalah keupayaan untuk mempengaruhi sekumpulan pekerja ke arah pencapaian matlamat (Robbins \& Coulter 2001). Seorang pemimpin yang berjaya mestilah mampu membina kepercayaan dengan memberikan lebih banyak kebebasan untuk bertindak secara autonomi dan membuat keputusan kepada pekerja. Di samping itu, pemimpin perlu menjelaskan hala tuju ke arah pencapaian matlamat kepada pekerja melalui komunikasi dan menggalakkan mereka untuk merasa yakin dan mampu untuk mengambil risiko dalam menyiapkan kerja. Kepimpinan juga dilihat sebagai proses untuk mempengaruhi kumpulan dan masa tertentu yang mana boleh mempengaruhi ahli organisasi untuk berusaha secara sukarela untuk mencapai matlamat bersama (Yulk 1998). Kepimpinan melibatkan kedua-dua keupayaan dan kuasa untuk memberi keyakinan kepada orang lain agar berusaha ke arah satu matlamat dan menggunakan kemahiran atau kebolehan untuk membantu mencapaikannya.

Sesetengah organisasi menganggap bahawa politik organisasi adalah perkara yang membawa ke arah kebaikan terhadap hubungan antara pengurus dan pekerja. Kepimpinan membawa kepada hubungan yang positif terhadap politik organisasi (Yukl 1998). Kebiasaanya pemimpin yang mempunyai kepimpinan yang tinggi seperti berkarisma, berkomited, jujur dan setia kepada organisasi, maka ia melakukan politik organisasi untuk mencapai kepentingan bersama bukan peribadi semata-mata, contohnya menetapkan polisi dan peraturan syarikat untuk memastikan pekerja meningkatkan prestasi kerja mereka (Ferris \& King 1991; Gull \& Aylia 2012). Kepimpinan juga mendorong kepada berlakunya politik organisasi, contohnya majikan memberi kenaikan gaji dan pangkat kepada pekerja yang mencapai matlamat dan 
objektif syarikat. Tingkah laku politik organisasi ini dapat mempengaruhi pekerja untuk mengikut segala tugasan dan arahan yang diberikan oleh majikan (Pettigrew 1973). Pada masa yang sama, pekerja cenderung kepada rasa hormat kepada majikan kerana kebajikan mereka dijaga dengan baik dan adil dalam organisasi.

Selain bertindak sebagai pemboleh ubah bebas dan pemboleh ubah bersandar, kepimpinan juga berpontensi memainkan peranan sebagai pemboleh ubah perantara yang menghubungkan pelbagai faktor organisasi dengan politik organisasi. Dalam kajian ini, penyelidik meramalkan kepimpinan bertindak sebagai pemboleh ubah perantara yang menghubungkan keadilan organisasi dan politik organisasi. Kajian lepas menerangkan bahawa keadilan organisasi diperlukan untuk memastikan semua pentadbiran yang dilaksanakan adalah berkualiti kepada pekerja. Keadilan organisasi biasanya dipraktik dalam organisasi untuk mewujudkan persekitaran yang harmoni di kalangan pekerja (Leow \& Khong 2015). Ini menunjukkan yang mana pemimpin dan pengikut perlu mempunyai hubungan yang baik supaya dapat bersamasama mencapai objektif dan matlamat organisasi dengan baik. Jika pemimpin tidak mempraktik keadilan organisasi, maka kesan negatif diperolehi oleh pekerja seperti ketidakpuasan kerja, komitmen yang kurang dan motivasi yang rendah di tempat kerja (Ouyang et al. 2015).

Kajian lepas yang dibuat oleh Loi, Lam dan Chan (2012) membuktikan bahawa hasil interaksi dua hala antara kepimpinan dan keadilan prosedur memberi bukti empirikal yang mana kepimpinan boleh membantu organisasi untuk mempraktik prosedur yang adil bagi membantu pekerja supaya dapat berurusan dengan selamat di tempat kerja. Selain itu, untuk membentuk polisi dan prosedur yang lebih konsisten, tepat dan bebas dari unsur-unsur berat sebelah (Leventhal 1980). Organisasi juga memerlukan kepimpinan yang beretika untuk menguatkuasakan dan melaksanakan peraturan-peraturan prosedur. Kepimpinan yang berkesan boleh membantu pemimpin untuk menonjolkan keadilan prosedur kepada pekerja (Loi et al. 2012).

Dalam persekitaran organisasi, pengurus mempraktik keadilan organisasi dalam kepimpinannya adalah untuk menjaga hubungan antara pekerja dan majikan (Leow \& Khong 2015). Apabila pengurus menjalankan segala tugasnya dengan berlandaskan keadilan, maka pengurus dapat mengurangkan kerenggangan dan politik berlaku di dalam organisasi. Kebiasaanya, kesan negatif wujud sekiranya pekerja merasakan diri mereka diberi layanan yang tidak adil dan tanpa keprihatinan dari pihak majikan (Shin et al. 2015; Ouyang et al.2015). Oleh yang demikian, kepimpinan yang dijalankan mestilah dimasukkan unsur-unsur keadilan bagi mengelakkan berlakunya politik di tempat kerja. Dalam proses membuat keputusan dan strategi dilakukan berdasarkan ketulusan oleh pemimpin. Ini menunjukkan bahawa tindakan itu mengukuhkan hubungan antara pengurus dan pekerja kerana atas dasar kepercayaan yang ditunjukkan bagi memastikan tidak ada permainan politik berlaku dalam organisasi (Kacmar et al. 2013; Elbanna 2016). Kepimpinan mempunyai ciri-ciri untuk menerapkan pekerja atas dasar keadilan dan kesaksamaan dan pada masa yang sama, boleh mengurangkan persepsi politik organisasi di tempat kerja (Islam, Rehman \& Ahmed 2013).

Perhubungan antara keadilan organisasi, kepimpinan dan politik organisasi dalam kajian ini ditunjukkan melalui Rajah 1. Kajian ini juga mengetengah dua hipotesis iaitu:

$\mathrm{H}_{1}$ Kepimpinan mempunyai hubungan yang positif dan signifikan kepada hubungan antara keadilan pengagihan dan politik kepentingan diri.

$\mathrm{H}_{2}$ Kepimpinan mempunyai hubungan yang negatif dan signifikan kepada hubungan antara keadilan prosedur dan politik kerjasama pekerja-majikan. 


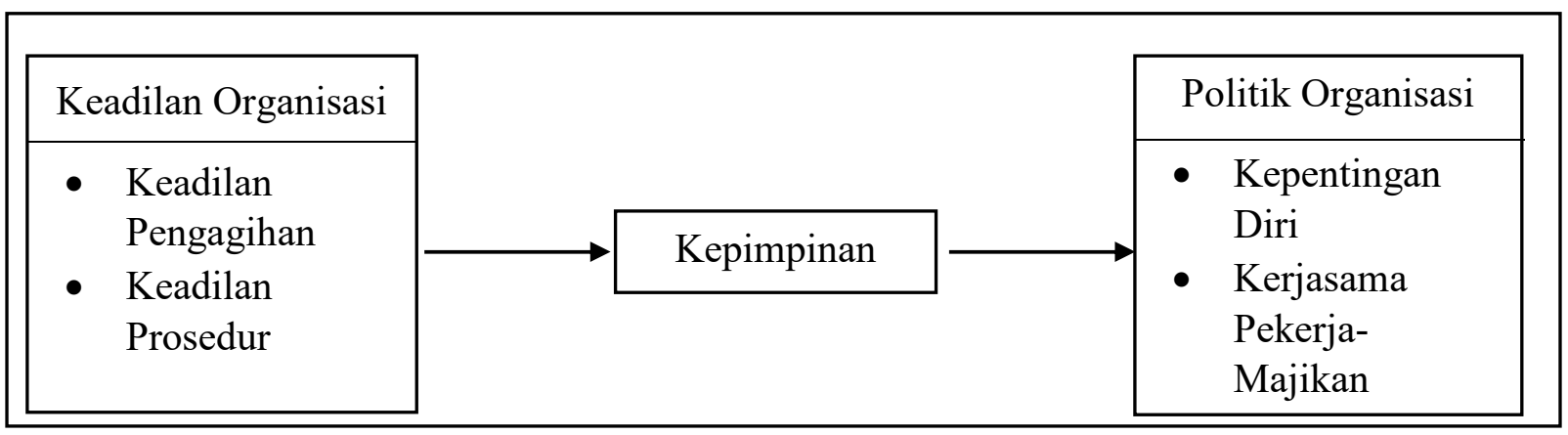

RAJAH 1. Kerangka Kajian

TEORI PERTUKARAN SOSIAL

Teori ini digunapakai untuk mengekalkan pertukaran hubungan dengan pihak lain dengan harapan untuk mendapat ganjaran (Homans 1961). Teori ini adalah terhad kepada tindakan yang bergantung kepada reaksi ganjaran daripada orang lain (Blau 1964) dan mengkaji keduadua belah bahagian iaitu saling memberi ganjaran yang dikenali sebagai "transaksi" dan hubungan yang dikenali sebagai "pertukaran" (Emerson 1976). Sehubungan itu, teori ini menggangap bahawa pihak-pihak yang berkepentingan sendiri akan membuat transaksi atau pertukaran dengan orang lain untuk mencapai sesuatu hasil yang tidak mampu dicapai oleh diri mereka sendiri dan pertukaran ini akan berhenti sebaik sahaja mereka tidak dilihat sebagai saling memberi ganjaran oleh kedua-dua pihak (Blau 1964). Pertukaran faedah atau memberikan sesuatu yang berharga kepada seseorang adalah asas utama bagi tingkah laku manusia (Homan 1961).

Penggunaan teori pertukaran sosial ini telah digunakan untuk melihat hubungan yang melibatkan pemboleh ubah perantara. Teori pertukaran sosial telah digunakan untuk menerangkan berkenaan dengan hubungan komitment sebagai pembolehubah perantara kepada hubungan antara sokongan dan niat. Kenyataan ini telah disokong kuat oleh Casimir et al. (2014), di mana teori pertukaran sosial telah diaplikasikan kepada hubungan antara pertukaran pemimpin-pengikut (LMX) dan sokongan organisasi terhadap prestasi kerja dan memasukkan faktor komitmen sebagai pembolehubah perantara. Di samping itu, penggunaan teori pertukaran sosial ini telah memberi impak yang besar terhadap hubungan yang melibatkan pembolehubah perantara.

Teori pertukaran sosial dilihat kepada dua faktor iaitu transaksi dan pertukaran yang berlaku di dalam organisasi. Bagi keadilan organisasi, transaksi berlaku apabila keadilan pengagihan dan keadilan prosedur memberi kesan kepada pengurangan politik organisasi di tempat kerja. Contohnya, sesebuah organisasi yang berpegang teguh kepada keadilan organisasi, maka pegangan dapat mengurangkan konflik atau pertikaian berlaku di kalangan pekerja. Kajian ini jelas menunjukkan bahawa transaksi berlaku di antara keadilan organisasi terhadap politik organisasi. Oleh yang demikian, penggunaan teori pertukaran sosial untuk melihat dengan lebih jelas lagi hubungan antara pembolehubah-pembolehubah. Pemilihan teori ini juga adalah selaras dengan rangka kajian yang telah dibina oleh penyelidik dalam kajian ini.

\section{METODOLOGI}

Sampel kajian merupakan golongan pekerja bukan pegawai di institusi kewangan Islam di Semenanjung Malaysia. Memandangkan politik organisasi sering berlaku dalam organisasi yang mana melibatkan golongan pekerja bawahan (Zulkiflee et al. 2013), maka bilangan pekerja bukan pegawai yang ramai di institusi kewangan Islam berpotensi sebagai tumpuan 
kajian. Sebanyak 1146 set soal selidik telah diedarkan ke institusi kewangan Islam. Kajian ini hanya menggunakan sebanyak 291 soal selidik untuk dianalisis yang mana merujuk kepada jadual yang dicadangkan oleh Kriejcie dan Mogan (1970).

Sampel kebarangkalian digunakan untuk menentukan sampel dalam kajian ini. Zikmund et al. (2010), menjelaskan bahawa semua teknik persampelan kebarangkalian adalah berdasarkan kepada prosedur pemilihan peluang. Ini kerana proses persampelan kebarangkalian adalah rawak, dan unsur berat sebelah yang wujud dalam prosedur persampelan bukan kebarangkalian dihapuskan. Teknik persampelan kebarangkalian adalah dilihat sebagai satu teknik yang mana setiap ahli populasi diketahui dan bukan kebarangkalian pemilihan (Zikmund et. al. 2010). Setiap ahli dalam populasi mempunyai kebarangkalian yang sama dipilih (Cavana, Delahaye \& Sekaran 2001). Oleh yang demikian, jumlah sampel disediakan melalui prosedur persampelan berstrata tidak seimbang (disproportional stratified sampling procedure). Persampelan berstrata tidak seimbang adalah sampel berstrata yang mana saiz sampel bagi setiap strata diperuntukkan mengikut pertimbangan analisis (Zikmund et. al. 2010).

Soal selidik kajian ini dilakukan dengan menggunakan kaedah tinggal dan ambil "drop and collect" seperti yang cadangkan oleh McCarthy, O'Reilly dan Cronin (2001). Semua soal selidik diedarkan kepada ibu pejabat negeri dan seluruh cawangan dalam Semenanjung Malaysia. Pengedaran soal selidik kepada setiap cawangan seluruh negeri diuruskan oleh ibu pejabat negeri masing-masing. Sebelum soal selidik dijawab oleh responden, pegawai yang ditugaskan serta memahami tentang kajian ini memberikan penerangan ringkas berkenaan dengan objektif kajian. Responden dinasihatkan untuk menjawab semua soalan soal selidik dalam masa 30 minit dan selepas itu, soal selidik dikembalikan kepada cawangan masingmasing. Apabila semua soal selidik dikutip, maka ia diserahkan kembali kepada ibu pejabat negeri masing-masing untuk diambil semula oleh penyelidik.

Skor min demografi (umur dan tempoh perkhidmatan) dan min pemboleh ubah kajian (keadilan organisasi; kepimpinan; politik organisasi) antara kedua-dua kumpulan tersebut telah dibandingkan dengan menggunakan t-test. Keputusan $t$-test menyatakan tidak ada perbezaan dalam min demografi dan min pemboleh ubah antara kumpulan yang uji, dan ini menerangkan bahawa tidak berlaku non-response bias. Maklumat keputusan demografi juga menunjukkan bahawa majoriti responden adalah terdiri daripada lelaki $(58.8 \%)$ dan berkahwin $(81.1 \%)$. Seterusnya purata umur bagi responden ialah 38 tahun (sisihan piawai $=9.93$ ), manakala purata tempoh perkhidmatan ialah 14 tahun (sisihan piawai $=10.1$ ). Majoriti responden iaitu 58.4\% mendapat pendidikan sehingga ke peringkat Sijil Pelajaran Malaysia (SPM).

\section{PENGUKURAN}

Politik organisasi diukur menggunakan 31 item daripada Skala Persepsi Politik Organisasi (Ferris \& Kacmar 1992). Pengukuran ini diguna pakai untuk melihat persepsi politik organisasi terhadap pekerja yang mana skala ini mengenal pasti tiga dimensi iaitu tingkah laku politik umum (General Behavior), mempengaruhi untuk bekerjasama bagi mendapat kepentingan (Get Along to Get Ahead), dan polisi pembayaran gaji dan promosi (Pay and Promotion Policies). Ketiga-tiga faktor untuk skala item politik organisasi ini termasuklah "individu dalam usaha untuk membina diri melalui orang lain", "Memberitahu orang lain apa yang mereka ingin ketahui adalah kadang-kadang lebih baik daripada memberitahu yang benar" dan "dasar gaji dan kenaikan pangkat yang dinyatakan tidak mempunyai apa-apa kaitan dengan bagaimana kenaikan gaji dan kenaikan pangkat ditentukan" (Danaeefard, Balutbazeh $\&$ Kashi 2010). Skor dilakukan menggunakan skala persetujuan bermula daripada " 1 = Sangat Tidak Setuju: kepada "4 = Sangat Setuju". Skor tinggi menerangkan politik organisasi yang 
tinggi dan sebaliknya. Nilai kebolehpercayaan untuk pengukuran politik organisasi ialah $\alpha=$ 0.91 .

Keadilan organisasi diukur dengan menggunakan tiga dimensi keadilan iaitu keadilan pengagihan, keadilan prosedur dan keadilan interaksi (Colquitt 2001). Keadilan pengagihan diukur dengan menggunakan empat item yang disahkan, contohnya "Hasil dari kerja saya adalah dari usaha saya sendiri". Keadilan prosedur diukur dengan menggunakan tujuh item, contohnya "Saya diberi peluang untuk menyatakan pendapat dan pandangan saya terhadap prosedur kerja saya". Manakala bagi keadilan interaksi diukur dengan menggunakan Sembilan item, contohnya "Saya sentiasa dilayan dengan penuh kesopanan oleh penyelia". Skor dilakukan menggunakan skala persetujuan bermula daripada " 1 = Sangat Tidak Setuju: kepada "4 = Sangat Setuju". Skor tinggi menerangkan keadilan organisasi yang tinggi dan sebaliknya. Nilai kebolehpercayaan untuk pengukuran keadilan organisasi ialah $\alpha=0.89$.

Kepimpinan diukur dengan menggunakan amalan Leadership Performance Inventory (LPI) yang diperkenalkan oleh Lopez (2012). Pengukuran ini digunakan untuk mengukur tingkah laku pemimpin terhadap pekerja dalam organisasi. Pengukuran Amalan Kepimpinan Inventori (LPI) dinilai dengan menggunakan 30 item, contohnya "Penyelia saya menetapkan tingkah laku yang diharapkan untuk semua pekerja", "Penyelia saya sentiasa berpegang kepada janji dan komitmen yang telah ditetapkan", dan "Penyelia saya selalu memberikan kebebasan dan pilihan kepada pekerja dalam menentukan bagaimana untuk melakukan kerja mereka". Skor dilakukan menggunakan skala persetujuan bermula daripada "1 = Sangat Tidak Setuju: kepada " 4 = Sangat Setuju". Skor tinggi menerangkan kepimpinan yang tinggi dan sebaliknya. Nilai kebolehpercayaan untuk kepimpinan ialah $\alpha=0.95$.

Ketiga-tiga instrumen pemboleh ubah diadaptasikan dari kajian lepas yang mana penyelidik telah mengubah item-item soal selidik mengikut kesesuaian persekitaraan tempat kajian tanpa mengubah maksud asal soalan tersebut.

\section{ANALISIS DATA}

Data yang diperolehi dalam kajian ini dianalisis dengan menggunakan ujian kebolehpercayaan, analisis faktor dan analisis regresi berganda. Ujian kebolehpercayaan diguna pakai untuk melihat sejauh mana skala adalah bebas daripada kesilapan dan menghasilkan keputusan yang kosisten antara pemboleh ubah - pemboleh ubah (Gay \& Diehl 1996). Analisis faktor digunakan untuk menentukan dimensi pemboleh ubah yang mana ia merupakan satu proses untuk menentukan dimensi asas yang merangkumi dalam pemboleh ubah (Hair Jr. et al. 2010). Penggunaan analisis faktor juga untuk meringkaskan maklumat yang terkandung dalam sejumlah besar pemboleh ubah ke dalam jumlah faktor yang lebih kecil (Zikmund et al. 2010). Manakala analisis regresi berganda adalah untuk meramal pemboleh ubah bersandar dengan set pemboleh ubah tidak bersandar. Analisis regresi berganda merupakan teknik statistik yang boleh digunakan untuk menganalisis hubungan antara pemboleh ubah bersandar tunggal (kriteria) dan beberapa pemboleh ubah tidak bersandar (peramal) (Hair Jr. et al. 2010). Akhir sekali, kajian ini juga menggunakan analisis regresi berganda untuk melihat kesan perantara dalam hubungan antara pemboleh ubah bebas dan pemboleh ubah bersandar.

\section{PEMERIKSAAN DATA}

Pemeriksaan data dilakukan untuk melihat proses kebolehpercayaan dan data normal dalam kajian ini. Keputusan pemeriksaan data menunjukkan bahawa nilai kebolehpercayaan politik organisasi ialah $\alpha=0.716$, keadilan organisasi ialah $\alpha=0.907$, dan kepimpinan ialah $\alpha=0.956$. Dalam data normal, ujian Skewness dan Kurtosis membuktikan bahawa ketiga-tiga pemboleh 
ubah masih berada dalam \pm 1.96 . Oleh yang demikian, politik organisasi, keadilan organisasi dan kepimpinan adalah data normal.

\section{ANALISIS FAKTOR}

Analisis faktor untuk pembolehubah politik organisasi menunjukkan bahawa nilai KMO ialah 0.771 dan ujian Barlett's adalah signifikan pada $p<0.05$. Kajian ini membuktikan terdapat sembilan faktor dengan skor nilai Eigen melebihi 1 dan jumlah kumulatif varians diterangkan ialah 61.205\%. Dalam Matrik Komponen Berputar menunjukkan terdapat tujuh komponen (faktor 3, faktor 4, faktor 5, faktor 6 faktor 7, faktor 8 dan faktor 9) tidak mencapai tahap kebolehpercayaan 0.7 (Hair, Jr. et al. 2010). Dengan demikian, ia tidak diambil untuk analisis lanjut.

JADUAL 1. Ujian kebolehpercayaan untuk politik organisasi selepas analisis faktor

\begin{tabular}{lc}
\hline Politik Organisasi & Nilai kebolehpercayaan $(\alpha)$ selepas analisis faktor \\
\hline Faktor 1 (kepentingan diri) & 0.701 \\
Faktor 2 (kerjasama pekerja-majikan) & 0.768 \\
\hline
\end{tabular}

Jadual 1 menerangkan nilai kebolehpercayaan untuk politik organisasi selepas proses analisis faktor. Faktor 1 mengandungi enam item yang mana nilai kebolehpercayaan ialah 0.701. Berdasarkan maksud setiap item, penyelidik telah menamakan sebagai politik kepentingan diri. Bagi faktor 2 mengandungi enam item yang mana nilai kebolehpercayaan ialah 0.768. Merujuk kepada maksud setiap item, faktor ini dinamakan sebagai politik kerjasama pekerja-majikan. Selain itu, dua dimensi ini juga dinamakan berdasarkan kajian lepas yang telah dibuat oleh Saiful Azizi dan Zulkiflee (2016). Hanya dua faktor politik organisasi yang dilanjutkan kepada analisis seterusnya.

Analisis faktor untuk keadilan organisasi menunjukkan bahawa nilai KMO ialah 0.884 . Ujian Barlett's adalah signifikan pada $p<0.05$. Terdapat lima faktor yang ditunjukkan dalam nilai skor Eigen melebihi 1 dan jumlah kumulatif varians diterangkan ialah 67.415\%. Dalam Matrik Komponen Berputar menerangkan bahawa terdapat satu komponen (faktor 5) perlu dibuang daripada analisis seterusnya kerana tidak mencapai tahap kebolehpercayaan yang baik.

JADUAL 2. Ujian kebolehpercayaan untuk keadilan organisasi selepas analisis faktor

\begin{tabular}{lc}
\hline Keadilan Organisasi & Nilai kebolehpercayaan $(\alpha)$ selepas analisis faktor \\
\hline Faktor 1 (Penjelasan Aspek) & 0.914 \\
Faktor 2 (Keikhlasan) & 0.890 \\
Faktor 3 (Keadilan Pengagihan) & 0.728 \\
Faktor 4 (Keadilan Prosedur) & 0.716 \\
\hline
\end{tabular}

Jadual 2 menunjukkan bahawa nilai kebolehpercayaan $(\alpha)$ untuk keadilan organisasi selepas analisis faktor. Faktor 1 mengandungi enam item yang mana nilai kebolehpercayaan ialah 0.914. Berdasarkan maksud item, maka faktor ini dinamakan sebagai penjelasan aspek. Faktor 2 mengandungi enam item yang mana nilai kebolehpercayaan ialah 0.890 dan dinamakan sebagai keikhlasan. Faktor 3 mengandungi empat item dengan nilai kebolehpercayaan adalah 0.728 dan dinamakan sebagai keadilan pengagihan. Akhir sekali, faktor 4 mengandungi empat item dengan nilai kebolehpercayaan adalah 0.716 dan dinamakan sebagai keadilan prosedur. Pemberian nama untuk faktor 3 dan faktor 4 adalah seperti mana dicadangkan oleh Colquitt (2001). Oleh yang demikian, keempat-empat faktor tersebut dibawa kepada analisis seterusnya.

Analisis faktor diguna pakai untuk melihat dimensi-dimensi dalam setiap pemboleh ubahpemboleh ubah yang diukur yang menggunakan instrumen berdimensi. Oleh itu, kajian ini 
tidak menjalankan analisis faktor kepada pemboleh ubah perantara (kepimpinan) kerana instrumen yang diguna pakai untuk mengukur kepimpinan dalam kajian ini adalah kurang dari 5 item dan tidak perlu dijalankan analisis faktor (Hishamuddin 2008).

\section{ANALISIS REGRESI}

\section{POLITIK KEPENTINGAN DIRI}

Dalam analisis regresi antara Keadilan Organisasi, satu kes dibuang dalam ujian Casewise Diagnostic. Nilai Dublin-Watson adalah 1.835, di mana nilai ini menunjukkan bahawa tidak wujud pelanggaran sisa (violation of residual). Dalam Jadual 3 keputusan analisis regresi menunjukkan bahawa terdapat dua pembolehubah tidak bersandar iaitu Keadilan Pengagihan, Keadilan Prosedur yang mempengaruhi terhadap Politik Kepentingan Diri. Nilai $R^{2} 0.103$. Bermakna 10.3\% daripada varians Politik Kepentingan Diri.

Keputusan analisis regresi menerangkan Penjelasan Aspek, Keikhlasan, Keadilan Pengagihan dan Keadilan Prosedur mempunyai pengaruh yang signifikan terhadap Kepimpinan. Nilai $R^{2} 0.714$, bermakna $71.4 \%$ daripada varian Kepimpinan disumbangkan oleh gabungan Penjelasan Aspek $(\beta=0.566)$, Keikhlasan $(\beta=0.264)$, Keadilan Pengagihan $(\beta=$ 0.149), Keadilan Prosedur $(\beta=0.058)$.

Keputusan kajian ini yang ditunjukkan dalam Jadual 3 membuktikan bahawa Kepimpinan yang mempunyai pengaruh signifikan terhadap Politik Kepentingan Diri. Nilai $\mathrm{R}^{2}$ adalah 0.360 bersamaan dengan 36\% varian Politik Kepentingan Diri disumbangkan oleh Kepimpinan.

\section{POLITIK KERJASAMA PEKERJA-MAJIKAN}

Dari keputusan analisis regresi untuk Keadilan Organisasi terhadap Politik Kerjasama PekerjaMajikan, lapan kes telah dibuang dalam ujian Casewise Diagnostic. Nilai Dublin-Watson adalah 2.143, di mana nilai ini menunjukkan bahawa tidak wujud pelanggaran sisa (violation of residual). Dalam Jadual 4, keputusan analisis regresi menunjukkan bahawa terdapat Keadilan Prosedur yang mempengaruhi terhadap Politik Kerjasama Pekerja-Majikan. Nilai $R^{2}$ 0.347, bermakna 34.7\% daripada varian Politik Kerjasama Pekerja-Majikan disumbangkan oleh gabungan Penjelasan Aspek $(\beta=0.031)$, Keikhlasan $(\beta=-0.047)$, Keadilan Pengagihan $(\beta=0.001)$, dan Keadilan Prosedur $(\beta=-0.184)$.

Keputusan ujian Regresi menunjukkan bahawa Penjelasan Aspek, Keikhlasan, Keadilan Pengagihan dan Keadilan Prosedur mempunyai pengaruh yang signifikan terhadap Kepimpinan. Nilai $R^{2} 0.714$, bermakna $71.4 \%$ daripada varian Kepimpinan disumbangkan oleh gabungan Penjelasan Aspek $(\beta=0.566)$, Keikhlasan $(\beta=0.264)$, Keadilan Pengagihan $(\beta=$ $0.149)$, dan Keadilan Prosedur $(\beta=0.058)$.

Jadual 4 menunjukkan bahawa hanya Kepimpinan mempunyai pengaruh signifikan terhadap Politik Kerjasama Pekerja-Majikan. Nilai $\mathrm{R}^{2} 0.470$ bersamaan dengan $47 \%$ varian Politik Kerjasama Pekerja-Majikan disumbangkan oleh Kepimpinan.

\section{PERANAN KEPIMPINAN SEBAGAI PERANTARA DALAM HUBUNGAN ANTARA KEADILAN ORGANISASI DAN POLITIK ORGANISASI}

Keputusan analisis regresi menerangkan bahawa Kepimpinan memberi kesan perantara kepada hubungan antara Keadilan Prosedur dan Politik Kepentingan Diri. Ini jelas dibuktikan dalam Jadual 4.26 yang mana nilai beta menurun dari $-0.208^{*}$ kepada $-0.200^{*}$. Menurut Baron dan Kenny (1986), penurunan nilai Beta dari Model 1 (IV-DV) kepada Model 4 (IV-MV-DV) dianggap sebagai Perantara Sebahagian (Partial Mediation). Oleh itu, kajian ini menunjukkan 
bahawa Kepimpinan menjadi pemboleh ubah perantara kepada hubungan antara Keadilan Prosedur dan Politik Kepentingan Diri.

JADUAL 3. Rumusan ujian perantara (Kepimpinan) dalam hubungan antara keadilan organisasi dan politik kepentingan diri

\begin{tabular}{lcccc}
\hline Pemboleh ubah & Model 1 & Model 2 & Model 3 & Model 4 \\
\hline Penjelasan Aspek & IV-DV & IV-MV & MV-DV & IV-MV-DV \\
Keikhlasan & -0.133 & $0.566^{*}$ & & -0.057 \\
Keadilan Pengagihan & -0.011 & $0.264^{*}$ & & 0.024 \\
Keadilan Prosedur & $0.193^{*}$ & $0.149^{*}$ & & $0.212^{*}$ \\
Kepimpinan & $-0.208^{*}$ & $0.058^{*}$ & & $-0.200^{*}$ \\
DF & & & $-0.489^{*}$ & \\
Nilai F & 63.464 & 32.241 & 63.307 & 62.378 \\
$R^{2}$ & $4.879^{*}$ & $105.908^{*}$ & $9.584^{*}$ & $4.403^{*}$ \\
\hline
\end{tabular}

Nota: *Signifikan pada paras keyakinan $\mathrm{p}<0.05$

Dapatan analisis regresi yang ditunjukkan dalam Jadual 4 menerangkan bahawa Kepimpinan tidak memberi kesan perantara kepada hubungan antara Keadilan Organisasi terhadap Politik Kerjasama Pekerja-Majikan. Walaupun Keadilan Prosedur mempunyai hubungan yang signifikan dalam Model 1 (IV-DV) dan Model 4 (IV-MV-DV) tetapi nilai Beta bertambah dari $-0.184 *$ kepada $-0.201 *$. Menurut Baron dan Kenny (1986), apabila nilai Beta bertambah dari Model 1 kepada Model 4, maka ia dianggap sebagai tiada kesan perantara.

JADUAL 4. Rumusan ujian perantara (Kepimpinan) dalam hubungan antara keadilan organisasi dan politik kerjasama pekerja-majikan

\begin{tabular}{lcccc}
\hline & Model 1 & Model 2 & Model 3 & Model 4 \\
Pemboleh ubah & IV-DV & IV-MV & MV-DV & IV-MV-DV \\
\hline Penjelasan Aspek & 0.031 & $0.566^{*}$ & & -0.124 \\
Keikhlasan & -0.047 & $0.264^{*}$ & & -0.115 \\
Keadilan Pengagihan & 0.001 & $0.149^{*}$ & & -0.035 \\
Keadilan Prosedur & $-0.184^{*}$ & $0.058^{*}$ & & $-0.201^{*}$ \\
Pengasingan & $0.452^{*}$ & 0.014 & & $0.452^{*}$ \\
Penganiayaan & 0.094 & 0.044 & & 0.079 \\
Kepimpinan & & & $-0.597^{*}$ & \\
DF & 45.969 & 32.241 & 58.693 & 61.576 \\
F value & $21.913^{*}$ & $105.908^{*}$ & $2.491^{*}$ & $20.532^{*}$ \\
$R^{2}$ & 0.347 & 0.714 & 0.470 & 0.369 \\
\hline
\end{tabular}

Nota: *Signifikan pada paras keyakinan $\mathrm{p}<0.05$

Kajian ini membuktikan bahawa kepimpinan hanya memainkan sebagai perantara dalam hubungan antara keadilan prosedur dengan politik kepentingan diri.

\section{PERBINCANGAN}

Kajian ini bertujuan meneliti keadilan pengagihan memberi kesan yang positif dan signifikan kepada politik kepentingan diri. Keadilan pengagihan adalah merujuk kepada keadilan dalam pengagihan tugas dan penilaian prestasi. Ini membawa maksud dalam menjalankan tugas-tugas di cawangan, pengurus merujuk kepada deskripsi dan spesifikasi kerja seseorang pekerja. Tugas yang diberikan perlulah selaras dengan tugas dan tanggungjawab serta kelayakan dan kebolehan seseorang pekerja. Prestasi kerja dinilai di akhir tahun yang mana secara umumnya, 
prestasi yang rendah diberikan hukuman, contohnya amaran lisan dan manakala prestasi yang tinggi mendapat penganugerahan dari organisasi. Keadilan dalam pengagihan tugas dan penilaian prestasi mendorong pekerja untuk mencapai kecekapan dan keberkesanan dalam pekerjaan dan seterusnya mencapai KPI cawangan yang menjadi matlamat utama seseorang pengurus cawangan. Oleh yang demikian, boleh dikatakan bahawa keadilan pengagihan memberi kesan yang signifikan kepada politik kepentingan diri seseorang pengurus. Ini selari dengan kajian lepas yang dibuat oleh Kimura (2013) menyatakan bahawa pengurus yang mempunyai komitmen yang baik dalam menguruskan pekerjanya, secara tidak langsung memudahkan lagi untuk melakukan politik organisasi terhadap pekerja supaya mereka melakukan sebarang tugasan atau pekerjaan dengan baik tanpa bantahan.

Kajian ini juga mendapati keadilan prosedur mempunyai pengaruh terhadap politik kepentingan diri. Pengaruh keadilan prosedur mengurangkan kesan kepada politik kepentingan diri adalah wajar kerana pengurus lebih memberi komitmen semasa menjalankan tugas mereka. Ini disokong oleh Cobb dan Frey (1996), apabila prosedur kerja dianggap sebagai garis panduan yang perlu dipatuhi di tempat kerja, maka pengurus lebih komited dengan kerja mereka. Semua pengurus mengambil berat tentang tanggungjawab dan peranan kerja masingmasing kerana prosedur kerja memberi impak sama ada positif kepada diri sendiri atau organisasi, contohnya dalam pengurusan yang berkaitan dengan siasatan dalaman (domestic inquiry). Ini disokong oleh Shrestha dan Mishra (2015) yang mana menyatakan bahawa pengurus yang sentiasa berkomited dalam melakukan tugasnya, maka pengurus tersebut tidak cenderung ke arah tingkah laku politik organisasi.

Kebiasaanya dalam institusi kewangan Islam di Malaysia, pengurus memainkan peranan penting untuk memberikan pekerja kenaikan pangkat dalam organisasi yang mana pengurus perlu mematuhi prosedur kenaikan pangkat yang ditetapkan oleh pihak atasan iaitu berdasarkan gred prestasi pekerja, contohnya gred A (cemerlang), gred B (baik), gred C (memuaskan) dan gred D (kurang memuaskan). Dalam prosedur kenaikan pangkat, pengurus dan pegawai jabatan sumber manusia menjadi panel dalam penilaian terhadap kenaikan pangkat untuk pekerja. Sebagai panel yang bertanggungjawab dalam menentukan sama ada pekerja layak untuk dinaikan pangkat atau tidak, mereka perlu membuat keputusan dengan suci hati 'bonafide'.

Apabila wujudnya 'bonafide' dalam keputusan yang dibuat oleh panel, maka tidak perlu ada perbincangan di antara panel dan pekerja. Jika berlaku keputusan yang tidak suci hati 'malafide', perkara ini mendorong kepada pertikaian di antara panel dan pekerja yang mana pihak majikan perlu berbincang dengan kesatuan sekerja. Keadilan prosedur menjalankan kerja secara 'bonafide' dalam organisasi. Ini dapat menggambarkan di mana apabila majikan dapat mengikut prosedur yang betul dalam membuat keputusan, maka secara tidak langsung dapat mengurangkan berlakunya politik organisasi. Kewujudan keadilan prosedur menunjukkan bahawa majikan tidak perlu lagi bermain politik untuk mendapatkan kerjasama pekerja dalam proses membuat atau menentukan keputusan. Ini selari dengan dapatan kajian ini di mana keadilan prosedur mempunyai hubungan yang negatif dan signifikan terhadap politik kerjasama pekerja-majikan. Ini disokong oleh Vigoda-Gadot (2013), menyatakan bahawa tingkah laku politik organisasi dapat memberi kepuasan kerja kepada pekerja sekiranya ia dilakukan dengan betul dan adil.

Kajian ini turut mengesahkan peranan kepimpinan sebagai perantara dalam menghubungkan keadilan prosedur dan politik kepentingan diri. Keadilan prosedur sememangnya mewujudkan politik dalam institusi kewangan Islam di Malaysia tetapi jika ada pengaruh kesan kepimpinan, maka keadilan prosedur menjadi semakin besar. Ini menunjukkan bahawa apabila pengurus mengikut prosedur yang dipersetujui antara pekerja dan majikan, maka pengurus tidak melakukan diskriminasi atau memanipulasikan kuasanya kepada pekerja. Namun begitu, jika terdapat campur tangan atau pengaruh kepimpinan sebagai perantara, maka keadilan dalam menjalankan prosedur ini menjadi lebih adil dan saksama. 
Dalam persekitaran organisasi, pengurus memain peranan penting dalam menjalankan penilaian prestasi kepada pekerja dengan adil. Untuk memastikan penilaian prestasi dijalankan dengan adil dan saksama, maka pengurus mempraktik prosedur yang ditetapkan oleh organisasi. Kebiasaanya dalam proses penilaian prestasi, pertama pengurus memberi borang penilaian prestasi kepada pekerja untuk menilai diri mereka sendiri. Kedua, borang penilaian prestasi tersebut dipulangkan kepada pengurus untuk dinilai oleh pengurus dan ketiga, pengurus membuat penilaian prestasi berdasarkan borang penilaian yang dikembalikan dan persepsi pengurus itu sendiri terhadap pekerjanya. Ini menunjukkan bahawa pengurus menjalankan proses penilaian prestasi dengan mengikut semua prosedur yang telah ditetapkan oleh pihak organisasi.

Kajian lepas yang dibuat oleh Loi et al. (2012) membuktikan bahawa hasil interaksi dua hala antara kepimpinan dan keadilan prosedur memberikan bukti empirikal yang mana kepimpinan boleh membantu organisasi untuk mempraktik prosedur yang adil bagi membantu pekerja supaya dapat berurusan dengan selamat di tempat kerja. Selain itu, untuk membentukkan polisi dan prosedur yang lebih konsisten, tepat dan bebas dari unsur-unsur berat sebelah, organisasi juga memerlukan kepimpinan yang beretika untuk menguatkuasakan dan melaksanakan peraturan-peraturan prosedur (Leventhal 1980). Kepimpinan yang berkesan boleh membantu pemimpin untuk menonjolkan keadilan prosedur kepada pekerja (Loi et al. 2012). Oleh yang demikian, adalah lebih manfaat bagi organisasi apabila memiliki keadilan prosedur dan kepimpinan yang tinggi di tempat kerja kerana dapat menangani persepsi kerja yang tidak selamat dengan berkesan.

Keadilan prosedur memainkan peranan penting dalam memastikan segala polisi dan peraturan yang dibuat di tempat kerja adalah tidak mendorong kepada kesan berat sebelah (Cropanzano, Bowen \& Gilliland 2007). Ini menunjukkan bahawa pemimpin perlu membuat keputusan berdasarkan polisi dan peraturan-peraturan syarikat serta menitikberatkan isu-isu keadilan bagi mencapai kepuasan pekerja dalam organisasi (Greenberg 1993). Situasi ini membuktikan yang mana keadilan prosedur lebih konsisten sekiranya pemimpin sentiasa mengambil berat tentang keadilan dan kesaksamaan di tempat kerja. Oleh yang demikian, kajian ini mendedahkan bahawa kepimpinan mempunyai pengaruh perantara antara keadilan prosedur dan politik kepentingan diri.

\section{IMPLIKASI TEORI}

Teori pertukaran sosial diguna pakai untuk menerangkan pertukaran hubungan dengan pihak lain dengan harapan untuk mendapat ganjaran yang berpatutan (Blau 1964). Teori ini adalah terhad kepada tindakan yang bergantung kepada reaksi ganjaran daripada orang lain dan mengkaji kedua-dua belah bahagian iaitu saling memberi ganjaran yang dikenali sebagai "transaksi" dan hubungan yang dikenali sebagai "pertukaran". Sehubungan itu, teori ini menganggap bahawa pihak-pihak yang berkepentingan sendiri akan membuat transaksi atau pertukaran dengan orang lain untuk mencapai sesuatu hasil yang mereka sendiri tidak mampu mencapainya dan pertukaran ini akan berhenti sekiranya mereka tidak dilihat sebagai saling memberi ganjaran oleh kedua-dua pihak.

Penggunaan teori pertukaran sosial juga digunakan dalam institusi kewangan seperti perbankan. Teori pertukaran sosial adalah bertujuan untuk membangunkan satu perspektif pertukaran sosial pakatan strategik dyadic rancangan jangka pendek. Dalam kajian ini pendekatan konsep lukisan pada teori pertukaran sosial diguna pakai untuk mendapatkan kesimpulan inovatif mengenai pakatan strategik dyadic jangka pendek. Tambahan itu, penggunaan teori pertukaran sosial ini boleh membantu pengurus dan penganalisis bekerja di perbankkan pelaburan untuk memahami punca ketidakstabilan perikatan dan kegagalan dalam industri mereka. Teori pertukaran sosial ini signifikan digunakan dalam sektor kewangan 
terutamanya syarikat kewangan Islam dalam kajian berkenaan dengan politik pejabat adalah kerana untuk melihat hubungan yang berlaku di antara pertukaran dan transaksi pengurus dan pekerja. Ini kerana dalam institusi kewangan yang berkonsepkan Islam lebih menitikberatkan tentang hubungan yang adil dan saksama berlaku di dalam organisasi, contohnya transaksi yang berlaku dalam hubungan antara keadilan prosedur terhadap politik kepentingan diri yang mana kepimpinan menjadi agen pertukaran dalam hubungan tersebut. Oleh yang demikian, ini menunjukkan bahawa teori pertukaran sosial sesuai diguna pakai dan dipraktik di dalam institusi kewangan Islam.

Dalam kajian lepas yang berkaitan dengan politik organisasi, teori pertukaran sosial masih belum digunakan untuk melihat hubungan atau pengaruh di antara politik organisasi dan pemboleh ubah - pemboleh ubah yang lain. Kebiasaannya penyelidik lepas menggunakan teori pertukaran sosial ini untuk melihat pengaruh yang berkaitan dengan sokongan organisasi (Wayne, Shore \& Liden 2007), tingkah laku kewarganegaraan (Cropanzano \& Mitchell 2005), dan keadilan organisasi (Aryee \& Budhwar 2002). Oleh itu, disebabkan tidak ada kajian yang menggunakan teori pertukaran sosial dalam politik organisasi, maka kajian ini akan menambahkan ilmu baru dalam bidang kajian politik organisasi.

Teori pertukaran sosial telah mencadangkan dua pemboleh ubah dalam pertukaran iaitu pertukaran sosial dan pertukaran ekonomi (Miles 2012). Pertukaran ekonomi dilihat sebagai pulangan ke atas pelaburan seseorang yang lebih jelas dikenali dan sering dinyatakan seperti mana di dalam kontrak bertulis. Pertukaran ekonomi ini adalah berasas kepada transaksi jangka masa yang pendek. Kajian ini telah menggunakan teori pertukaran sosial untuk melihat kesan keadilan organisasi (ekonomi) terhadap politik organisasi yang lebih terjurus kepada ganjaran tidak ketara (intangible rewards). Manakala pertukaran sosial pula dilihat sebagai pulangan ke atas pelaburan seseorang yang tidak ditentukan dan sering dilakukan secara sukarela. Pertukaran sosial adalah berdasarkan kepada hubungan di mana kedua-dua pihak percaya bahawa yang lain agak memenuhi tanggungjawab mereka dalam jangka masa yang panjang (Holmes 1981). Kajian ini mengaplikasikan teori pertukaran sosial untuk melihat kesan keadilan (sosial) terhadap politik organisasi yang lebih berbentuk kepada tingkah laku. Oleh yang demikian, kajian ini melebarkan lagi penggunaan teori pertukaran sosial dalam bidang perusahaan. Dalam bidang perusahaan ini adalah fokus dalam mengkaji tentang hubungan di antara majikan dan pekerja dalam organisasi.

\section{IMPLIKASI PENGURUSAN}

Manakala implikasi pengurusan, tujuan utama politik organisasi boleh dilihat kepada dua sudut iaitu sudut positif dan negatif. Kebanyakkan penyelidik lepas melakukan kajian berkenaan dengan politik organisasi adalah cenderung kepada sudut negatif yang mana politik organisasi boleh membawa kepada berlakunya konflik di kalangan pekerja (Ullah et al. 2011; Yen, Chen \& Yen 2009). Walau bagaimanapun, politik organisasi juga memberi kesan yang positif dari aspek kuasa dan authoriti. Ini disokong oleh Pettigrew (1973) melihat politik organisasi sebagai satu permainan yang berlaku apabila seseorang pekerja atau sekumpulan pekerja mahu memajukan diri atau idea mereka yang mana melalui kaedah pengaruh.

Penggunaan kuasa dan authoriti adalah penting dalam menjalankan gelagat politik organisasi di tempat kerja. Ini kerana penggunaan kuasa dan authoriti yang salah boleh menyebabkan berlakunya konflik di kalangan pekerja. Dapatan kajian ini mempunyai beberapa implikasi praktis terhadap pengurus-pengurus di Institusi Kewangan Islam untuk memastikan keharmonian industri wujud di kalangan pekerja dalam organisasi. Berdasarkan kepada dapatan kajian, beberapa elemen keadilan organisasi seperti penjelasan aspek, keikhlasan, keadilan pengagihan dan keadilan prosedur adalah antara elemen yang akan dipertimbangkan oleh pengurus untuk memastikan keharmonian wujud di kalangan pekerja. Pengurus-pengurus 
Institusi Kewangan Islam perlu mengambil kira akan kepentingan keadilan organisasi terutamanya keadilan prosedur dan keadilan pengagihan.

Kajian ini menunjukkan keadilan prosedur memberikan kesan terhadap kepentingan diri dan kerjasama pekerja-majikan yang merupakan dimensi kepada politik organisasi dalam kajian ini. Arah kesan adalah negatif di mana ia membawa implikasi bahawa semakin tinggi keadilan prosedur, maka semakin kurang pihak pengurusan memikirkan kepentingan diri dan juga mengurangkan pihak pengurusan mengambil peluang mencapai matlamat peribadinya melalui kerjasama pekerja-majikan. Keadilan prosedur merupakan satu perkara yang perlu diambil serius dalam pentadbiran kerana keputusan melalui prosedur yang dipersetujui bersama pekerja dapat mewujudkan persekitaran kerja yang harmoni iaitu bebas daripada sifat berat sebelah atau pilih kasih di dalam organisasi. Apabila pengurus menjalankan keadilan prosedur dalam pentadbiran mereka, maka secara tidak langsung pengurus dapat mengurangkan kepentingan diri mereka kerana mereka akan lebih berkomited dalam menjalankan tugas mereka dalam organisasi. Kewujudan keadilan prosedur akan mendorong pengurus institusi kewangan Islam supaya sentiasa mengambil berat tentang tanggungjawab dan peranan kerja kerana prosedur akan menjadi garis panduan dalam diri pengurus untuk menjalankan pentadbirannya dengan telus dan adil, contohnya dalam pengurusan pelaksanaan siasatan dalaman. Sehubungan itu, apabila pengurus mematuhi segala prosedur dan peraturan yang telah ditetapkan untuk menyelesaikan masalah yang berkaitan dengan pekerjaan, maka keadaan ini akan menunjukkan tentang akautabiliti dan integriti dalam pentadbiran mereka.

Kepimpinan yang berkualiti merupakan kepimpinan yang boleh membawa perubahan kepada organisasi, sikap dan tingkah laku pekerja (Hizam, Jaafar \& Zahir 2000). Ini juga turut menyumbang kepada kesan keadilan prosedur terhadap politik kepentingan diri. Dalam kajian ini menunjukkan bahawa seseorang pengurus perlu memainkan peranan penting dalam menjalankan sesuatu tugasan dengan berlandaskan kepada prosedur yang telah dipersetujui antara pekerja dan majikan. Dalam institusi kewangan Islam, pengurus akan menjalankan pentadbiran mereka dengan berlandaskan kepada lima nilai teras iaitu profesionalisme, kerja berpasukan, komited, prihatin, mesra dan penyayang dan inovatif. Apabila pengurus sentiasa berpegang kepada lima nilai teras ini, maka pengurus akan lebih menitikberatkan tentang prosedur syarikat. Ini kerana prosedur syarikat yang wujud dalam institusi kewangan Islam adalah merupakan garis panduan kepada pengurus supaya sebarang pelaksanaan kerja berlaku dengan adil dan saksama kepada pekerja. Oleh yang demikian, pengurus yang berkarisma akan sentiasa mematuhi prosedur syarikat dan seterusnya mencapai objektif syarikat dengan baik.

\section{KESIMPULAN}

Kajian ini mendedahkan tentang pemboleh ubah-pemboleh ubah yang mempengaruhi politik organisasi. Terdapat satu faktor yang mempengaruhi berlakunya politik organisasi iaitu keadilan organisasi. Sehubungan itu, terdapat dua faktor yang mempengaruhi politik kepentingan diri iaitu keadilan pengagihan dan keadilan prosedur. Untuk politik kerjasama pekerja-majikan, kajian ini mendedahkan bahawa hanya satu faktor yang mempengaruhi iaitu keadilan prosedur. Walau bagaimanapun, kajian ini juga telah membuktikan bahawa kepimpinan hanya memainkan peranan sebagai perantara dalam hubungan antara keadilan prosedur dan politik kepentingan diri di institusi kewangan Islam di Malaysia.

\section{RUJUKAN}

Ambrose, M.L. \& Schminke, M. 2009. The role of overall justice judgements in organizational justice research: A test of mediation. Journal of Applied Psychology 29(2): 491-500. 
Atinc, G., Darrat, M., Fuller, B. \& Parker, B.W. 2010. Perceptions of organizational politics: A meta analysis of theoretical antecedents. Journal of Managerial Issues 22(4): 494-513.

Bakshi, A., Kumar, K. \& Rani, E. 2009. Organizational justice perceptions as predictor of job satisfaction and organizational commitment. International Journal of Business and Management 4(9): 145-154.

Baron, R.M. \& Kenny, D.A. 1986. The moderator-mediator variable distinction in social psychological research: Conceptual, strategic, and statistical considerations. Journal of Personality and Social Psychology 51(6): 1173-1182.

Bies, R.J. \& Moag, J.F. 1986. Interactional Justice: Communication criteria of fairness. Research on Negotiation in Organizations 1: 43-55.

Blau, P.M. 1964. Exchange and Power in Social Life. Hoboken. NJ: Wiley.

Brown, M.E. \& Trevino, L.K. 2006. Ethical leadership: A review and future directions. Leadership Quartely 17: 595-616.

Brown, M.E., Trevino, L.K. \& Harrison, D.A. 2005. Ethical leadership: A social learning perspective for construct development and testing. Organizational Behavior and Human Decision Process 97: 117-134.

Casimir, G., Ng, Y.N.K., Wang, K.Y. \& Ooi, G. 2014. The relationships amongst leadermember exchange, perceived organizational support, affective commitment, and in-role performance: A social-exchange perspective. Leadership \& Organization Development Journal 35(5): 366-385.

Cavana, R.Y., Delahaye, B.L. \& Sekaran, U. 2001. Applied Business Research: Qualitative and Quantitative Methods. New York: John Wiley \& Sons Australia, Ltd.

Cobb, A.T. \& Frey, F.M. 1996. The effects of leader fairness and pay outcomes on superior/subordinate relations. Journal of Applied Social Psychology 26: 1401-1426.

Colquitt, J.A. 2001. On the dimensionality of organizational justice: A construct validation of a measure. Journal of Applied Psychology 86: 386-400.

Colquitt, J.A., Conlon, D.E., Wesson, M.J., Porter, C.O.L.H. \& Ng, K.Y. 2001. Justice at the millennium: A meta-analytic review of 25 years of organizational justice research. Journal of Applied Psychology 86: 425-445.

Colquitt, J.A., Rodell, J.B., Zapata, C.D., Scott, B.A., Long, D.M., Conlon, D.E. \& Wesson, M.J. 2013. Justice at the millennium, a decade later: A meta-analytic test of social exchange and affect-based perspectives. Journal of Applied Psychology 98(2): 199-236.

Cropanzano, R., Bowen, D.E. \& Gilliland, S.W. 2007. The management of organizational justice. Academy of Management Perspective 11: 34-48.

Danaeefard, H., Balutbazeh, A.E. \& Kashi, K.H.A. 2010. Good soldiers' perceptions of organizational politics understanding the relation between organizational citizenship behaviors and perceptions of organizational politics: Evidence from Iran. European Journal of Economics, Finance, and Administrative Sciences 18(1): 146-162.

Doldor, E. 2007. Conceptualizing and investigating organizational politics: A systematic review of the literature (MRes dissertation). Available at https://dspace.lib.cranfield.ac. uk/bitstream/1826/5419/1/Elena_Doldor_Thesis_2007.pdf.

Elbanna, S. 2016. Managers' autonomy, strategic control, organizational politics and strategic planning effectiveness: An empirical investigation into missing links in the hotel sector. Tourism Management 52: 210-220.

Emerson, R.M. 1976. Social exchange theory. Annual Review of Sociology 2: 335-362.

Ferris, G.R. \& Kacmar, K.M. 1992. Perception of organizational politics. Journal of Management 18: 93-116.

Feris, G.R. \& King, T.R. 1991. Politics in human resource decisions: A walk on the dark side. Organizational Dynamics 20(2): 59-71. 
Fernandes, C. \& Awamleh, R. 2006. Impact of organizational justice in an international work environment. Management Research News 29(11): 701-712.

Gandz, J. \& Murray, V.V. 1980. The experience of workplace politics. Academy of Management Journal 23: 237-251.

Gay, L.R. \& Diehl, P.L. 1996. Research Methods for Business and Management. Singapore: International Edition. Simon \& Schruster (Asia) Pte. Ltd.

Greenberg, J. 1986. Determinants of perceived fairness of performance evaluation. Journal of Applied Psychology 71: 340-342.

Greenberg, J. 1990. Employee theft as a rection to underpayment inequity: The hidden cost of pay cuts. Journal of Applied Psychology 75: 561-568.

Gull, S. \& Aylia, A.Z. 2012. Impact of organizational politics on employees' job satisfaction in the health sector of Lahore Pakistan. Interdisciplinary Journal of Contemporary Research in Business 4(2): 156-170.

Hair, Jr. J.F., Anderson, R.E., Tatham, R.L. \& Black, W.C. 2010. Multivariate Data Analysis. 7th ed. Upper Saddle River, NJ: Pearson.

Hishamuddin, M.S. 2008. Panduan Mudah Analisis Data Menggunakan SPSS Windows. Skudai, Malaysia: Universiti Teknologi Malaysia.

Homans, G.C. 1961. Social Behavior: Its Elementary Forms. New York: Harcourt Brace.

Islam, T., Rehman, S.U. \& Ahmed, I. 2013. Investigating the mediating role of organizational politics between leadership style and followers' behavioral outcomes. Business Strategy Series 14(2/3): 80-96.

Iqbal, K. 2013. Determinants of organizational justice. International Review of Management and Business Research 2(1).

Kacmar, K.M., Andrews, M.C., Harris, K.J. \& Tepper, B.J. 2013. Ethical leadership and subordinate outcomes: The mediating role of organizational politics and the moderating role of political skill. Journal of Business Ethic 115: 33-44.

Kacmar, K.M. \& Baron, R.A. 1999. Organizational politics: The state of the field links to related processes and an agenda for future research. In Research in Personnel and Human Resources Management, edited by G.R. Ferris. Greenwich, CT: JAI Press.

Kacmar, K.M. \& Ferris, G.R. 1992. Perception of organizational politics scale (POPS): Development and construct validation. Educational \& Psychological Measurement 51: 193-205.

Khan, K., Abbas, M., Gul, A. \& Raja, U. 2015. Organizational justice and job outcomes: Moderating role of Islamic work ethic. Journal of Business Ethics 126: 235-246.

Kimura, T. 2013. The moderating effects of political skill and leader-member exchange on the relationship between organizational politics and affective commitment. Journal of Business Ethics 116(3): 587-599.

Krejcie, R.V. \& Morgan, D.W. 1970. Determining sample size for research activities. Educational and Psychological Measurement 30: 607-610.

Kurchner-Hawkins, R. \& Miller, R. 2006. Organizational politics: Building positive political strategies in turbulent times. In Handbook of Organizational Politics, edited by E. VigodaGadot \& A. Drory, 358-351. Cheltenham, UK: Edward Elgar.

Leventhal, G.S. 1980. What should be done with equity theory? New approaches to the study of fairness in social relationships. In Justice, morality, and social responsibility, edited by D.P. Skarlicki, 1-28. Charlotte, NC: Information Age Publishing.

Loi, R., Lam, L.W. \& Chan, K.W. 2012. Coping with job security: The role of procedural justice, ethical leadership and power distance orientation. Journal of Business Ethics 108: 361-372. 
Leow, K.L. \& Khong, K.W. 2015. Organizational commitment: The study of organizational justice and leader-member exchange (LMX) among auditors in Malaysia. International Journal of Business and Information 4(2): 161-198.

Lopez, A. 2012. Leadership Practices Inventory (LPI): Individual Feedback Report. Available at http://leadwithcorevalues.com.

Madison, D.L. 1980. Organization politics: an exploration of managers' perceptions. Journal of Human Relation 33(2): 79-100.

McCarthy, M., O'Reilly, S. \& Cronin, M. 2001. Psychological, attitudinal and behavioural characteristics of Irish speciality cheese customers. British Food Journal 103(5): 313-330.

McDowall, A. \& Fletcher, C. 2004. Employee development organizational justice perspective. Personnel Review 33(1): 8-29.

Mintzberg, H. 1985. The organizations as a political area. Journal Management Studies 22(2): 133-154.

Mohd Noor, Z., Mohd Amir, A. \& Maelah, R. 2017. Hubungan sistem pengukuran prestasi strategik dan prestasi pensyarah di universiti penyelidikan awam Malaysia melalui keadilan organisasi. Jurnal Pengurusan 51: 235-248.

Moorman, R.H. 1991. Relationship between organizational justice and organizational citizenship behaviours: do fairness perceptions influence employee citizenship? Journal of Applied Psychology 76: 845-855.

Ouyang, Z., Sang, J., Li, P. \& Peng, J. 2015. Organizational justice and job insecurity as mediator of the effect of emotional intelligence on job satisfaction: A study from China. Personality and Individual Differences 76: 147-152.

Pettigrew, A. 1973. The Politics of Organizational Decision-Making. London: Tavistock.

Preffer, J. 1992. Managing with Power: Politics And Influence in Organizations. Boston: Harvard Business School Press.

Robbins, S.P. \& Coulter, M. 2001. Management. New York: Prentice Hall.

Saiful Azizi, I. \& Zulkiflee, D. 2016. The impact of organizational justice on organizational politics at Islamic financial based organizational in Malaysia. International Journal of Research in Humanities and Social Studies 3(4): 1-7.

Sarminah, S. 2011. Examining the effects of emotional intelligence on the relationship between organizational politics and job performance. International Journal of Business and Social Science 2(6): 119-126.

Shin, Y., Sung, S.Y., Choi, J.N. \& Kim, M.S. 2015. Top management ethical leadership and firm performance: Mediating role of ethical and procedural justice climate. Journal of Business Ethics 129: 43-57.

Shrestha, A.K. \& Mishra, A.K. 2015. Interactive effects of public service motivation and organizational politics on Nepali civil service employees' organizational commitment. Business Perspectives and Research 3(1): 21-35.

Sikora, D.M. \& Ferris, G.R. 2014. Strategic human resource practice implementation: The critical role of line management. Human Resource Management Review 24: 274-281.

Suliman, A.M.T. 2007. Is it really a mediating construct? The mediating role of organizational commitment in work climate-performance relationship. Journal of Management Development 21(3): 170-183.

Thibaut, J. \& Walker, L. 1978. A theory of procedure. California Law Review 66: 541-566.

Ullah, S., Jafri, A.R. \& Dost, M.K. 2011. A synthesis of literature on organizational politics. Far East Journal of Psychology and Business 3(3): 36-49.

Unit Perancangan Ekonomi, Jabatan Perdana Menteri. 2010. Rancangan Malaysia Kesepuluh 2011-2015. Putrajaya: Author. Available at http://www.pmo.gov.my/ dokumenattached/RMK/RMK10_Mds.pdf 
Vigoda, E. 2000. Organizational politics, job attitudes, and work outcomes: Exploration and implications for the public sector. Journal of Vocational Behavior 57: 326-347.

Vigoda-Gadot, E. 2006. Leadership style, organizational politics, and employees' performance: An empirical examination of two competing models. Emerald Group Publishing Limited 36: 661-683.

Yen, W.W., Chen, S.C. \& Yen, S.I. 2009. The impact of perceptions of organizational politics on workplace friendship. African Journal of Business Management 3(10): 548-554.

Yukl, G. 1998. Leadership in Organizations. 4th ed. Englewood Cliffs, NJ: Prentice-Hall.

Zhang, Y., LePine, J.A., Buckman, B.R. \& Wei, F. 2014. It's not fair...or is it? The role of justice and leadership in explaining work stressor-job performance relationships. Academy of Management Journal 57(3): 675-697.

Zikmund, W.G., Babin, B.J., Carr, J.C. \& Griffin, M. 2010. Business Research Methods. $8^{\text {th }}$ ed. Canada: South-Western, Cengage Learning.

Zulkiflee Daud, Mohd Faizal Mohd Isa, Wan Shakizah Wan Mohd Nor \& Zairani Zainol. 2013. Office politics: the reduction of employees' need for power. International Journal of Business and Social Science 4(11): 29-35.

Saiful Azizi Ismail

Pusat Pengajian Pengurusan Perniagaan

Kolej Perniagaan

Universiti Utara Malaysia

06010 Sintok, Kedah, Malaysia

E-Mel: saifulazizi@uum.edu.my

Zulkiflee Daud

Pusat Pengajian Pengurusan Perniagaan

Kolej Perniagaan

Universiti Utara Malaysia

06010 Sintok, Kedah, Malaysia

E-Mel: zulkiflee@uum.edu.my

Ahmad Fauzi Ahmad Zaini

Sekolah Perniagaan dan Perakaunan

Kolej Universiti Poly-Tech MARA Kuala Lumpur

Jalan 6/91, Taman Shamelin Perkasa

56100 Cheras, Kuala Lumpur, MALAYSIA.

E-Mel: ahmadfauzi@kuptm.edu.my 